\title{
Review \\ Multi-Target Approach of Murraya koenigii Leaves in Treating Neurodegenerative Diseases
}

\author{
Mario A. Tan ${ }^{1}$, Niti Sharma ${ }^{2, *}$ and Seong Soo A. An ${ }^{2, *}$ \\ 1 College of Science and Research Center for the Natural and Applied Sciences, University of Santo Tomas, \\ Manila 1015, Philippines; matan@ust.edu.ph \\ 2 Department of Bionano Technology, Gachon Bionano Research Institute, Gachon University, \\ 1342 Seongnam-daero, Sujung-gu, Seongnam-si 461-701, Gyeonggi-do, Korea \\ * Correspondence: nitisharma@gachon.ac.kr (N.S.); seongaan@gachon.ac.kr (S.S.A.A.); \\ Tel.: +82-31-750-8591 (N.S.); +82-31-750-8755 (S.S.A.A.)
}

Citation: Tan, M.A.; Sharma, N.; An, S.S.A. Multi-Target Approach of Murraya koenigii Leaves in Treating Neurodegenerative Diseases.

Pharmaceuticals 2022, 15, 188.

https://doi.org/10.3390/ph15020188

Academic Editors: Simona Sestito,

Simona Rapposelli and

Massimiliano Runfola

Received: 9 January 2022

Accepted: 27 January 2022

Published: 2 February 2022

Publisher's Note: MDPI stays neutral with regard to jurisdictional claims in published maps and institutional affiliations.

Copyright: (C) 2022 by the authors. Licensee MDPI, Basel, Switzerland. This article is an open access article distributed under the terms and conditions of the Creative Commons Attribution (CC BY) license (https:// creativecommons.org/licenses/by/ $4.0 /)$.

\begin{abstract}
Neurodegenerative diseases (NDs) mainly affect neurons and gradually lead to a loss of normal motor and cognitive functions. Atypical protein homeostasis-misfolding, aggregations and accumulations, oxidative stress, inflammation, and apoptosis-are common features in most NDs. To date, due to the complex etiology and pathogenesis of NDs, no defined treatment is available. There has been increasing interest in plant extracts as potential alternative medicines as the presence of various active components may exert synergistic and multi-pharmacological effects. Murraya koenigii (Rutaceae) is utilized in Ayurvedic medicine for various ailments. Pharmacological studies evidenced its potential antioxidant, anti-inflammatory, anticancer, hepatoprotective, immunomodulatory, antimicrobial, and neuroprotective activities, among others. In line with our interest in exploring natural agents for the treatment of neurodegenerative diseases, this review presents an overview of literature concerning the mechanisms of action and the safety profile of significant bioactive components present in $M$. koenigii leaves to support further investigations into their neuroprotective therapeutic potential.
\end{abstract}

Keywords: neurodegenerative disease; Murraya koenigii; essential oils; toxicity; carbazole alkaloids; natural products

\section{Introduction}

Neurodegenerative diseases (NDs) are a broad term used to define a range of disorders (Alzheimer's disease, Parkinson's disease, dementia with Lewy body, frontal temporal dementia, multiple sclerosis, amyotrophic lateral sclerosis, Huntington's disease, prion disease, and many more) primarily affecting the neurons and leading, ultimately, to the progressive loss of normal motor functions and the decline in cognitive functions. The brain region affected, severity, and pace of neurodegeneration vary with the type of ND. According to a recent report, around 50 million people worldwide have such diseases [1] The total number of Alzheimer's disease (AD) patients is estimated to be over 100 million by the year 2050 [2]. Similarly, the number of patients with Parkinson's disease (PD) is expected to double or more than double for populous countries such as China, India, and Indonesia [3].

The exact reasons for ND manifestation among some people and not for others are still not fully understood. Some NDs are suspected to occur due to genetic mutations; some are also linked to living conditions [4]. However, oxidative stress, atypical protein folding, inflammation, and apoptosis are common to the majority of NDs. Due to complex etiology and pathogenesis of NDs, to date, there are no defined treatments that can reverse the progressive degeneration of neurons and cure these diseases. Although research is progressing, drug development for NDs is slow. Over the past 30 years, only around 
22 drugs were developed for NDs [5] in comparison to cancer (128 drugs), which represented the highest number, followed by antibacterial, antiviral, and antihypertension drugs $(118,110$, and 79 drugs, respectively) [5]. Since many NDs are multifactorial, exploring bioactive compounds from the plants for their therapeutic potential is a safer alternative, as these bioactive compounds might act synergistically to alleviate NDs through a variety of pathways, such as preventing $A \beta$ formation, inhibiting neurotransmission enzymes, slowing protein aggregation, removing free radicals, and reducing inflammation [6-10].

Murraya koenigii (curry-leaf tree) was a small, tropical to sub-tropical shrub or tree growing up to $6 \mathrm{~m}$ in height, belonging to the family Rutaceae. It can be found in countries like India, Sri Lanka, and Bangladesh. Almost every part (fresh leaves, fruits, bark, and roots) of this plant is used in Indian traditional system of medicine (Ayurveda) to treat various ailments. The green curry leaves were generally used in treating piles, inflammation, itching, fresh cuts, dysentery, and edema. The roots were used for curing body aches while the bark was helpful in treating snakebites [11]. Fresh M. koenigii leaves are known for their signature aroma, slightly spicy and bitter taste; these characteristics are preserved even after drying. Fresh and dried curry leaves are considered as an important ingredient in South Indian cuisine and are broadly used for seasoning and flavoring dishes. The curry leaves have well established therapeutic potentials like hypoglycemic, hypolipidemic [12-15], nephroprotective [16,17], hepatoprotective [18,19], gastroprotective [20], cardioprotective [21,22], atherosclerotic [23] and cholesterol lowering effects in experimental animals [24]. The alcoholic leaf extract possessed antioxidant [25,26], analgesic, anti-inflammatory [27-29], antipyretic [30], antitrichomonal [31], antibacterial [32,33], antifungal [34], antileishmanial [35], antidiarrheal [36], wound-healing [37], anti-obesity [38], anticancer [39-41], and immunomodulatory activities $[42,43]$. The carbazole alkaloid mahanine, purified from the curry leaves, exerted anticancer activity [44-46] by acting as proteasome inhibitor [47,48] and displayed antihyperglycemic action [49].

This review is focused on the $M$. koenigii leaf extract and its bioactive components that exhibit neuroprotective effects through various mechanisms for the prevention and treatment in NDs. The literature search was conducted using Google Scholar and PubMed online databases until November 2021 with key words being neuroprotective, Murraya koenigii leaf, chemical composition and essential oils. Additionally, the safety evaluation of M. koenigii leaves is explored.

\section{Phytochemistry of Murraya koenigii}

Proximate analysis on the leaves of $M$. koenigii revealed the following contents: ash $(15.60 \% \pm 0.21)$, moisture $(23.40 \% \pm 0.10)$, protein $(8.38 \% \pm 0.02)$, fats $(6.48 \% \pm 0.22)$, carbohydrate $(39.44 \% \pm 0.04)$, and crude fiber $(6.30 \% \pm 0.05)$ [50]. Phytochemical screening utilizing the same leaves of the sample identified the composition (in mg per $100 \mathrm{~g}$ ) of various classes of secondary metabolites, including alkaloids (1.90 \pm 0.01$)$, flavonoids $(7.43 \pm 0.03)$, glycosides $(0.11 \pm 0.01)$, phenols $(4.25 \pm 0.04)$, saponins $(2.50 \pm 0.01)$, and tannins $(0.86 \pm 0.02)$ [50]. The leaves of $M$. koenigii are also a rich source of vitamins and minerals. The compositional analysis (in $\mathrm{mg}$ per $100 \mathrm{~g}$ ) revealed ascorbic acid (vitamin $\mathrm{C}$, $0.04 \pm 0.002$ ), $\beta$-carotene (vitamin $A, 6.04 \pm 0.02$ ), niacin (vitamin $B_{3}, 2.73 \pm 0.02$ ), riboflavin (vitamin $B_{2}, 0.09 \pm 0.002$ ), thiamin (vitamin B1, $0.89 \pm 0.01$ ), and $\alpha$-tocopherol (vitamin $\mathrm{E}$, $0.03 \pm 0.01$ [50]. Among the minerals analyzed, the following composition and amount were determined (in mg per $100 \mathrm{~g}$ ): calcium (19.73 \pm 0.02$)$, iron (0.16 \pm 0.01$)$, magnesium $(49.06 \pm 0.02)$, potassium (0.04 \pm 0.001$)$, sodium (16.50 \pm 0.21$)$, and zinc (0.04 \pm 0.001$)$ [50]. Interestingly, proximate, vitamins, and minerals analyses of the fruit pulp of $M$. koenigii revealed moisture content $(64.9 \%)$, total sugar $(9.76 \%)$, reducing sugar $(9.58 \%)$, ascorbic acid $(13.35 \%)$, calcium $(0.811 \%)$, iron $(0.007 \%)$, magnesium $(0.166 \%)$, phosphorous $(1.97 \%)$, and potassium $(0.082 \%)$ [51].

Many structurally diverse natural products were identified from $M$. koenigii, including the leaves, roots, stem bark, fruits, and seeds, using chromatographic and spectroscopic techniques. The isolation of terpenoids, alkaloids, flavonoids, coumarins, polyphenols, and 
essential oils was described in phytochemical studies searching for potential biologically active constituents [52,53]. In particular, M. koenigii was reported as a rich source of more than fifty carbazole-type alkaloids with potent pharmacological activities [50]. Cytotoxic activity was reported for the major alkaloids koenimbine, murrayafoline, mahanine, mahanimbine, isomahanine, murrayazoline, koenoline, mahanimboline, and mukoline [52,54]. Mahanimbinine, murrayacinine, mahanimboline, isomahanine, and mahanimbine possessed diverse pharmacological activities, including antioxidant, antimicrobial, antidiabetic, and antihyperlipidemic activities [52]. Other reported antioxidant carbazole alkaloids in $M$. koenigii included mukoeic acid, murrayanine, mukonicine, koenigine, koenine, 9formyl-3-methylcarbazole, murrayanol, and O-methylmurrayamine A, while additional antimicrobial alkaloids were girinimbine, murrayanine, mahanine, murrayacine, mukoline, and pyrafolione D [52,54]. Among the non-alkaloidal compounds identified in M. koenigii, the coumarins and flavonoids of catechin, epicatechin, quercetin, myricetin, naringin, and rutin were identified as antioxidant and anticancer compounds. Additionally, the polyphenolic compounds ferulic acid, gallic acid, and vanillic acid were reported to increase the antioxidant potential of M. koenigii [54].

Over 100 compounds were identified in the essential oils of $M$. koenigii leaves from different regions $[26,33,55,56]$. Monoterpenoids and sesquiterpenoids were reported in the leaf essential oils with therapeutic activities against various targets. Potential antioxidant and antimicrobial compounds from the essential oils of $M$. koenigii were alloocimene, $\alpha$-terpinene, $(E)$ - $\beta$-ocimene, elemol, linalool, geranyl acetate, and myrcene [54]. M. koenigii leaves collected from Tamilnadu, India, were extracted by hydrodistillation [26]. Gas chromatography-mass spectrometry (GC-MS) analysis of the essential oil indicated monoterpenes $(11.81 \%)$, sesquiterpenes $(3.12 \%)$, monoterpenoids $(72.15 \%)$, and sesquiterpenoids $(10.48 \%)$. Among the 33 compounds identified, allo-ocimene $(5.02 \%)$, (E)- $\beta$ ocimene $(3.68 \%)$, elemol $(7.44 \%)$, geranyl acetate $(6.18 \%)$, linalool $(32.83 \%)$, myrcene $(6.12 \%)$, $\alpha$-terpinene $(4.9 \%)$, and neryl acetate $(3.45 \%)$ were present in the highest amounts [26]. Leaf samples collected from Vietnam were separately extracted using conventional hydrodistillation (CHD) and microwave-assisted hydro-distillation (MHD) methods. The characterization of the essential oils obtained by CHD and MHD revealed terpene hydrocarbons (90.98\% and $95.79 \%$, respectively) and oxygenated hydrocarbons $(9.02 \%$ and $4.21 \%$, respectively. In total, 76 and 62 compounds were identified using the CHD and MHD extraction methods, respectively. $\alpha$-Pinene (19.03\%, CHD; 29.81\%, MHD), $\beta$-pinene (4.03\%, CHD), $\beta$ phellandrene (18.22\%, CHD; 25.62\%, MHD), trans- $\beta$-caryophyllene $(27.24 \%, \mathrm{CHD} ; 17.09 \%$, MHD), $\beta$-caryophyllene (4.87\%, CHD; 2.98\% MHD), and bicyclogermacrene (5.23\%, CHD; $3.21 \%$ MHD) were identified as the major constituents [33]. Moreover, the major components of $M$. koenigii essential oils from the London, United Kingdom were $\beta$-caryophyllene $(28.7 \%)$, $\beta$-gurjunene $(21.4 \%)$, selinene $(8.2 \%), \beta$-elemene $(6.8 \%)$; essential oil from Nigeria contained oxygenated compounds including $\beta$-caryophyllene $(20.5 \%)$, bicyclogermacrene (9.9\%), $\alpha$-cardinol (7.3\%), caryophyllene epoxide (6.4\%), and $\beta$-selinene $(6.2 \%)$; and samples from Bangladesh contained 3-carene (54.2\%) and caryophyllene (9.5\%) [33]. Fresh leaves of M. koenigii collected from Dehra Dun, India, were hydrodistilled and subjected to GC-MS analysis. Among the 34 compounds identified, major constituents were $\alpha$-pinene (51.7\%), sabinene $(10.5 \%), \beta$-pinene $(9.8 \%), \beta$-caryophyllene $(5.5 \%)$, limonene $(5.4 \%)$, bornyl acetate (1.8\%), terpinen-4-ol (1.3\%), $\gamma$-terpinene (1.2\%), and $\alpha$-humulene (1.2\%) [55]. M. koenigii fresh leaves were collected from six geographical locations in Malaysia and the essential oils were obtained by hydrodistillation [56]. Volatile compounds from these samples were identified as sesquiterpene hydrocarbons (36-49\%), oxygenated sesquiterpenes (23-47\%), oxygenated monoterpenes (6.3-35\%), and oxygenated diterpenes (2.6-3.1\%). Interestingly, all six essential oils identified $\beta$-caryophyllene (16.6-26.6\%) and $\alpha$-humulene $(15.2-26.7 \%)$ as the major volatile constituents. Nine minor compounds were also identified, including aromadendrene $(0.5-1.5 \%)$, caryophyllene oxide $(0.7-3.6 \%)$, $\beta$-elemene $(0.3-1.3 \%)$, juniper camphor (2.6-8.3\%), 2-naphthalenemethanol (0.7-4.8\%), $\beta$-selinene (3.8-6.5\%), spathulenol $(0.6-2.7 \%)$, viridiflorol $(1.5-5.5 \%)$, and trivertal $(0.1-1.0 \%)$ [56]. These results indicated vari- 
ations in the composition of the essential oils of $M$. koenigii depending on the geographical locations and conditions including soil type and climate [56,57].

\section{Phytochemicals of Murraya koenigii and Their Role in Neurodegenerative Diseases}

This section describes the neuroprotective effects of $M$. koenigii leaf extracts and specified metabolites against their potential targets in NDs. The oral administration of the leaf aqueous extract $(100,200,400 \mathrm{mg} / \mathrm{kg}$ body weight) to aluminum-treated rats was found to significantly restore antioxidant parameters (Catalase: CAT, Glutathione reduced: GSH, Lipid peroxidation: LPO), reversing them to normal through the neuroprotective properties of the extract [58]. The protective effect of $M$. koenigii on oxidative stress was most likely due to carbazole alkaloids, polyphenols, and flavonoids, which are known to have antioxidant properties [52,59,60]. Neuroprotective activity of the leaf aqueous extract $(100,200,400 \mathrm{mg} / \mathrm{kg}$ body weight) against paraquat $(10 \mathrm{mg} / \mathrm{kg}$ body weight/i.p. per week for 4 weeks)-induced Parkinsonism in rats was also studied. The leaf extract-treated animals performed better in behavioral and locomotor activities in comparison to the untreated group [61]. The possible neuroprotective potentials of a methanolic leaf extract were also observed in a two-vessel occlusion (2VO) rat model of partial global cerebral ischemia. Cognitive functions were evaluated by the Morris water maze test and the viable neurons were evaluated in the hippocampal region. The study results indicated cognitive improvement in the group treated with M. koenigii leaves methanolic extract [62]. Diazepam, scopolamine- and aging-induced amnesia behavioral models in rats were evaluated for memory enhancement after treatment with $M$. koenigii leaves (MKL). MKL (leaf powder mixed with wheat flour) were orally administered to various groups, and their behaviors were evaluated with the elevated plus-maze and Hebb-Williams maze trials. A significant dose-dependent improvement in the memory scores of young and aged rats was reported, and the significant reduction in amnesia could be due to the induction by scopolamine $(0.4 \mathrm{mg} / \mathrm{kg}$, i.p.) and diazepam $(1 \mathrm{mg} / \mathrm{kg}$, i.p.) in the treatment groups [63]. In addition, the acetylcholine esterase (AChE) activity and the total cholesterol were reported to be decreased in the groups fed on the MKL diet, suggesting a role of AChE and cholesterol in inducing nootropic effects in the animals [64]. Further studies were conducted on animal models to better understand the mechanism of cognitive improvement. The 15-day treatment with $M$. koenigii alkaloid extract (MKA) caused a dose-dependent reduction in AChE levels in the brain of aged mice. It also prevented the brain from age-induced oxidative stress by decreasing lipid peroxidation and nitric oxide levels and increasing the level of antioxidant enzymes (superoxide dismutase: SOD, CAT, GSH) in the brain $[65,66]$.

The neuroprotective potential of the carbazole alkaloid mahanimbine against lipopolysaccharides (LPS)-induced neuronal deficits in the SK-N-SH neuroblastoma cell line and its antioxidant potentials in the ICR mouse brain were evaluated. The pre-treatment of SK-NSH cells with mahanimbine significantly mitigated the generation of LPS-induced reactive oxygen species (ROS) in vitro. In addition, mahanimbine also inhibited the $\beta$-secretase $\left(\mathrm{IC}_{50} 4 \mu \mathrm{g} / \mathrm{mL}\right.$ ), which was responsible for production of $\beta$ amyloid $(\mathrm{A} \beta)$. In the in vivo study, mahanimbine supplementation re-equilibrated the levels of antioxidant markers (CAT, glutathione reductase: GR, malondialdehyde; MDA) in the brain in comparison to the untreated group [67]. Pre-treatment of LPS-challenged mice with mahanimbine enhanced the central cholinergic transmission by increasing acetylcholine (ACh) level through the AChE inhibition. Amyloidogenesis was also significantly decreased. Mahanimbine increased the levels of anti-inflammatory cytokines transforming growth factor- $\beta$ (TGF- $\beta$ ) and interleukin-10 (IL-10), and inhibited pro-inflammatory cytokines (IL-1 $\beta$ and tumor necrosis factor- $\alpha$ : TNF- $\alpha$ ). Decreased activity and expression of cyclooxygenase (COX-2) gene were observed with mahanimbine supplementation in the LPS-induced group. The overall findings supported the neuroprotective potential of mahanimbine against LPS-induced neuroinflammation [68]. The anti-AChE activity $\left(\mathrm{IC}_{50} 0.03 \mathrm{mg} / \mathrm{mL}\right)$ of mahanimbine was also established in vitro under acellular conditions [69]. 
A tricyclic sesquiterpene, isolongifolene (ILF), present in the essential oil of M. koenigii, was studied for its neuroprotective properties both in vitro [70] and in vivo [71]. ILF displayed effective scavenging activities in various antioxidant assays with $\mathrm{EC}_{50}$ values of $77.34,40.9,16.27,238.3,25.01,16.79,1.311,6.701,0.418 \mu \mathrm{g} / \mathrm{mL}$ in the 2,2-diphenyl1-picryl-hydrazyl-hydrate (DPPH), 2,2-azino-bis (3-ethylbenzothiazoline-6-sulfonic acid, ABTS), hydroxyl radical, nitric oxide, hydrogen peroxide, super oxide radical scavenging, ferric reducing antioxidant power (FRAP), total radical-trapping antioxidant parameter (TRAP) and reducing power assays, respectively [72]. ILF attenuated the rotenone-induced mitochondrial dysfunction and cell apoptosis in SH-SY5Y human neuroblastoma cells. ILF treatment improved the rotenone-induced oxidative stress, apoptosis, and mitochondrial dysfunction in vitro. ILF mitigated rotenone induced apoptosis by downregulating the expression of BCL2-associated X protein (Bax), caspases-3, 6, 8, and 9, cytosolic cytochrome complex (cyt c), and increasing the expression of B-cell lymphoma family of proteins (Bcl-2), along with increased mitochondrial cyt c. Additionally, the regulation of the expression of phosphoinositide 3-kinase (p-PI3K), protein kinase B ( $\mathrm{p}-\mathrm{AKT}$ ), and glycogen synthase kinase $3 \beta$ (p-GSK3 $\beta$ ) by ILF demonstrated its neuroprotective effects [70]. The $\mathrm{PI} 3 \mathrm{~K} / \mathrm{AKT} / \mathrm{GSK} 3 \beta$ signaling pathway is an important pathway for neuronal growth and function [73]. AKT regulated PI3K through the phosphorylation of GSK3 $\beta$, which was identified to be associated with various vital cellular functions, such as the regulation of cell apoptosis and survival [74]. The active form of GSK-3 $\beta$ (p-GSK-3 Tyr216) was reported to be increased in postmortem striata of PD patients [75]. These events occur through mitochondrially mediated cell death pathways [76], which involve the activation and localization of Bcl-2 and mitochondrial complex I activity [77]. In a separate study [71], ILF improved the oxidative stress condition and movement impairment induced by rotenone in a rat PD model. The co-administration of ILF and rotenone significantly restored the levels of antioxidant enzymes (SOD, CAT, and glutathione peroxidase (GPx)) and decreased the level of LPO. In addition, ILF improved the motor dysfunction in muscles and catalepsy that were induced by rotenone. This suggested that ILF could protect the dopaminergic neurons through free radical scavenging activity $[70,71]$.

A sesquiterpene alkene and atypical dietary cannabinoid, $\beta$-caryophyllene (BCP), is another essential bioactive compound in $M$. koenigii leaves [78]. It is a selective agonist of cannabinoid receptor 2 (CB2R), making it a favorable target for immune modulation, inflammation, and neuropathic pain conditions [79], and is involved in pathogenesis of cancer and NDs $[80,81]$. Through the CBR signaling pathways, the endocannabinoid system (ECS) controls stress linked to cognitive and emotional responses. The dysregulation of the ECS plays an important role in the pathogenesis and progression of various NDs, such as multiple sclerosis (MS), amyotrophic lateral sclerosis (ALS), and Alzheimer's disease (AD) [82,83]. In the brain of MS patients, aggregates of CB1R- and CB2R-expressing cells were found in the active multiple sclerosis plaques [84]. Similarly, in case of ALS patients, the increased CB2R-positive microglia and macrophages were present in the areas of motor neuron damage [85]. In $A D$, the altered expressions of $C B 1 R$ and $C B 2 R$ were observed in the brain [86-88]. In addition, increased levels of endocannabinoid degradation enzymes namely, fatty acid amide hydrolase (FAAH) and monoacylglycerol lipase (MAGL), were found in human AD brains $[87,89]$. Hence, reversing ECS dysregulation through the activation of $\mathrm{CB} 2 \mathrm{R}$ and the neuroprotection by BCP may influence the regulation of myelination and stimulating immune balance along with the inhibition of endocannabinoid degradation enzymes for their positive effects in NDs [90].

The effect of BCP on cognition was studied in a galactose (GAL) model of aging in mice. GAL induction lead to increased DNA oxidation in the prefrontal cortex and increased astrocyte numbers and interactions in the hippocampal region of the brain. Although the cognitive damage was not reversed by administering $\mathrm{BCP}$, it was able to block the increases in the number of astrocytes and DNA oxidation in mice treated with GAL. Hence, the neuroprotective effects of BCP were demonstrated at the molecular and cellular level in the GAL model of aging [91]. The protective effect of BCP was also seen in 
isolated macrophages and lymphocytes and in vivo models of experimental autoimmune encephalomyelitis (EAE) [92]. The in vitro neuroprotective effect of BCP was reported against the LPS-induced oligodendrocyte toxicity, which was facilitated through the nuclear factor-erythroid 2-related factor 2 and heme oxygenase-1 (Nrf2/HO-1) antioxidant defense pathway and peroxisome proliferator-activated receptor gamma (PPAR- $\gamma$ ) signaling pathways through CB2R binding [93]. Similarly, BCP (48 mg/kg) alleviated the Alzheimer-like diseases by modulating CB2R and PPAR- $\gamma$ signaling pathways in another study [94]. At $100 \mu \mathrm{M}, \mathrm{BCP}$ inhibited the expression of inducible nitric oxide synthetase (iNOS), interleukin (IL)-1 $\beta$, IL-6, and COX2 in C6 microglial cells, and decreased the level of nitric oxide and prostaglandin E2. These studies show that BCP had good neuroprotective potential, which may be related to the modulation of inflammatory mediators [95] in association with high mobility group box 1 and toll-like receptor 4 (HMGB1/TLR4) signaling [96], reducing oxidative stress and modulating CB2R [97-99].

Spathulenol (5,10-cycloaromadendrane), a tricyclic sesquiterpenoid, is a component of essential oil from the leaves of M. koenigii [100]. Spathulenol exerted neuroprotective effects against 6-hydroxydopamine (6-OHDA), a synthetic neurotoxin, in SH-SY5Y human dopaminergic neuroblastoma cells. Spathulenol not only relieved the generated oxidative stress in the cells due to 6-OHDG, but the mitochondrial membrane integrity was maintained, highlighting its potentials as a promising therapy for treating NDs [101].

(+)-3-Carene, a bicyclic monoterpenoid from $M$. koenigii leaf [78], was reported to be a potent uncompetitive inhibitor of $\mathrm{AChE}\left(\mathrm{IC}_{50} 0.2 \mathrm{mM}\right)$ [102]. A molecular docking study envisaging ligand-target interactions of essential oil components with human AChE, led to seven hit compounds, which formed favorable bonds at the enzyme active site. Hence, the in vitro evaluation led to the discovery of two new active hits, namely caryophyllene oxide $\left(\mathrm{IC}_{50} 5.3 \mu \mathrm{M}\right)$ and geranyl acetate ( $\left.\mathrm{IC}_{50} 244.5 \mu \mathrm{M}\right)$ [103], as components of essential oil from M. koenigii leaf $[26,78]$.

Linalool, a monoterpene alcohol, was also present in the essential oil of $M$. koenigii leaves. The improved cognitive-enhancing effects and anti-apoptotic activities in A $\beta 1-42$-treated rats could mostly result from its antioxidant potential [104]. In another study, linalool displayed neuroprotective potential in male Wistar rats after acrylamide $(50 \mathrm{mg} / \mathrm{kg}$ i.p.) treatment. Acrylamide was found in various food products during processing, which could present a potent neurotoxic effect in human and animals [105]. Linalool treatment (12.5 mg/kg i.p.) significantly reduced movement, which could be due to the acrylamide-induced abnormalities. Increased GSH levels in the rat brain could be regulated by linalool, indicating its role of antioxidant properties in neuroprotection [106]. In addition to improving cognitive functions, linalool displayed a neuroprotective effect through competitively inhibiting glutamate release and non-competitively blocking of N-methyl-D-aspartate (NMDA) receptors [107,108]. Moreover, it also decreased microgliosis and astrogliosis, reduced the formation of neurofibrillary tangles and $\beta$-amyloid plaques, and the levels of pro-inflammatory markers in the brain [109].

The neuroprotective effects of $\beta$-myrcene (MYR), a monoterpene present in the leaves of M. koenigii, were studied. MYR treatment protected the C57BL/J6 mice against oxidative stress, apoptosis, and histopathological damage induced by cerebral ischemia/reperfusion (I/R) [110].

The neuroprotective effect of nerolidol (NRD), a sesquiterpene alcohol, was discovered in the essential oil of $M$. koenigii leaves from the studies with a rotenone-induced model of PD [100]. NRD supplementation considerably improved the levels of oxidative stress markers (SOD, CAT, GSH, and MDA). NRD also inhibited the release of pro-inflammatory cytokines and inflammatory mediators. Moreover, NRD treatment prevented the rotenoneinduced activation of glial cells and the loss of dopaminergic neurons and nerve fibers, thus mitigating rotenone-induced dopaminergic neurodegeneration [111]. In another study, NRD significantly improved the locomotor activities and cognitive impairment, and reduced the AChE activity and reduction in oxidative stress [112]. Therefore, NRD displays 
its neuroprotective potential by antioxidant and anti-inflammatory action, which would be helpful in treating NDs.

Table 1 summarized the mechanism of action of different extracts and bioactive components in ameliorating the symptoms of NDs. Structures of the biologically active natural products of M. koenigii against various NDs are shown in Figure 1. A summative representation of the mechanism of action of the $M$. koenigii extracts and natural products are shown in Figure 2.<smiles>C=C1CC/C=C(/C)CC[C@@H]2[C@@H]1CC2(C)C</smiles>

$\beta$-Caryophyllene<smiles>C=C1CCC2OC2(C)CC[C@H]1C(C)(C)C</smiles>

Caryophyllene Oxide<smiles>CC(=O)OC/C=C(\C)CCC=C(C)C</smiles>

Geranyl acetate<smiles>CC1(C)C2=CCCC13CCC(C2)C3(C)C</smiles>

Isolongifolene<smiles>C=CC(C)(O)CCC=C(C)C</smiles>

Linalool<smiles>CC(C)=CCCC1(C)C=Cc2c(ccc3c2[nH]c2ccccc23)O1</smiles>

Mahanimbine<smiles>C=CC(=C)CCC=C(C)C</smiles>

B-Myrcene<smiles>C=CC(C)(O)CCC=C(C)CCC=C(C)C</smiles>

Nerolidol

Figure 1. Biologically active natural products from Murraya koenigii against neurodegenerative diseases.

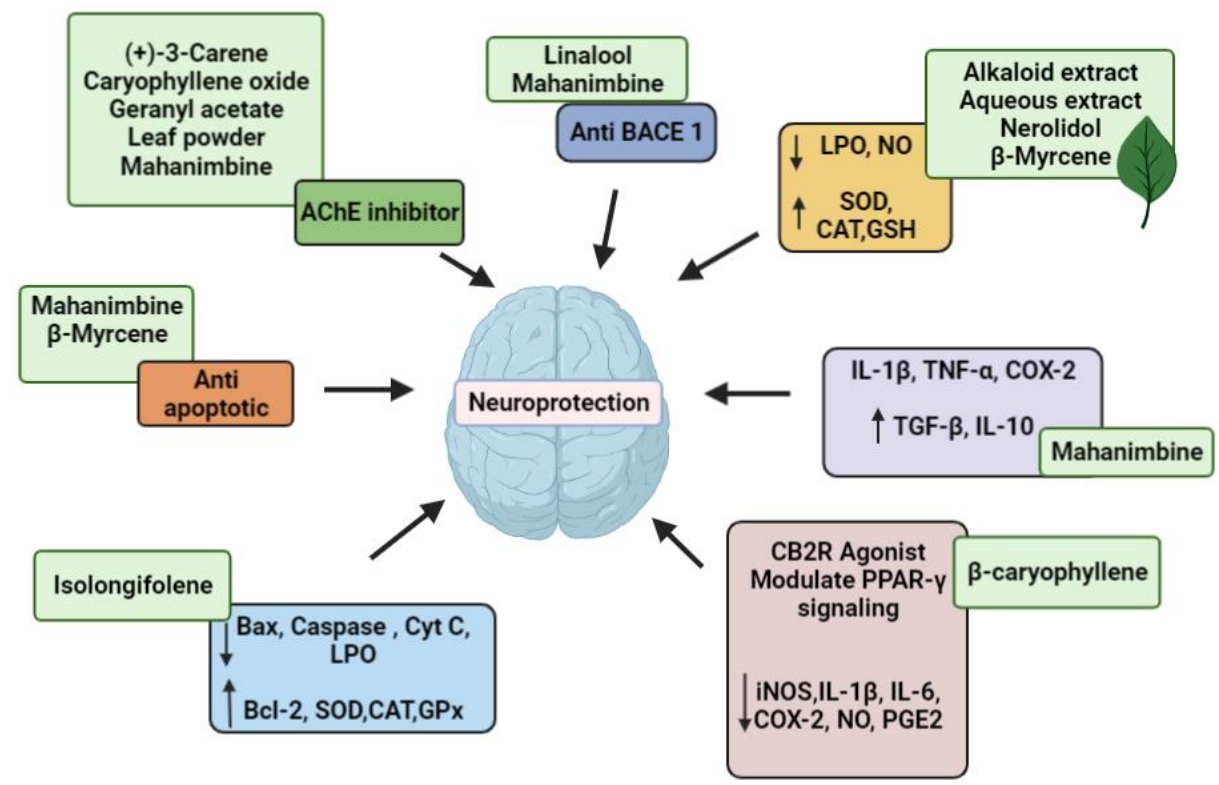

Figure 2. Mechanisms of action of the identified bioactive compounds from Murraya koenigii. 
Table 1. Mechanism of action of different extracts of Murraya koeingii leaves and their bioactive components in ameliorating symptoms of NDs.

\begin{tabular}{|c|c|c|c|c|}
\hline $\begin{array}{l}\text { Extract/Bioactive } \\
\text { Components }\end{array}$ & Model & Property & Neuroprotective Mechanism & Refs. \\
\hline Alkaloid extract & $\begin{array}{l}\text { Swiss Albino aged } \\
\text { mice (in vivo) }\end{array}$ & $\begin{array}{l}\text { Antioxidant } \\
\text { properties }\end{array}$ & $\begin{array}{c}\text { Reduced LPO, NO, } \\
\text { Increased SOD, CAT, GSH }\end{array}$ & {$[65,66]$} \\
\hline Aqueous extract & $\begin{array}{l}\text { Aluminum- } \\
\text { treated rats } \\
\text { (in vivo) }\end{array}$ & $\begin{array}{l}\text { Antioxidant } \\
\text { properties }\end{array}$ & $\begin{array}{c}\text { Decreased LPO, } \\
\text { Increased CAT, GSH }\end{array}$ & {$[58]$} \\
\hline Aqueous extract & $\begin{array}{l}\text { Paraquat-induced } \\
\text { Parkinsonism in rats } \\
\quad \text { (in vivo) }\end{array}$ & $\begin{array}{l}\text { Antioxidant } \\
\text { properties }\end{array}$ & $\begin{array}{c}\text { Better performance in behavioral and } \\
\text { locomotor activities, } \\
\text { Increased CAT, GSH, } \\
\text { Decreased LPO }\end{array}$ & {$[61]$} \\
\hline$\beta$-Caryophyllene & $\begin{array}{l}\text { Brain of patients } \\
\text { (Postmortum) } \\
\text { Galactose model of } \\
\text { aging mice (in vivo) } \\
\text { Autoimmune } \\
\text { encephalomyelitis } \\
\text { model (in vivo) } \\
\text { Isolated macrophages } \\
\text { and lymphocytes } \\
\text { (in vitro) }\end{array}$ & $\begin{array}{l}\text { Agonist of CB2R } \\
\text { Antioxidant } \\
\text { properties, } \\
\text { Anti-inflammatory }\end{array}$ & $\begin{array}{c}\text { Activation of CB2R, } \\
\text { Block the increases in the number of } \\
\text { astrocytes and the DNA oxidation, } \\
\text { Modulated CB2R and PPAR- } \gamma \text { signaling } \\
\text { pathways, } \\
\text { Inhibited expression of iNOS, IL-1 } \beta \text {, IL- } 6 \text {, } \\
\text { and COX- } 2 \text { and decreased the level of nitric } \\
\text { oxide and prostaglandin } \mathrm{E}_{2}\end{array}$ & {$[84,86-88,91,92,94]$} \\
\hline$(+)$-3-Carene & In vitro & Enzyme inhibition & Uncompetitive inhibitor of $\mathrm{AChE}$ & {$[102]$} \\
\hline Caryophyllene oxide & In vitro, in silico & Enzyme inhibition & Inhibitor of $\mathrm{AChE}$ & [103] \\
\hline Geranyl acetate & In vitro, in silico & Enzyme inhibition & Inhibitor of $\mathrm{AChE}$ & {$[103]$} \\
\hline Isolongifolene & $\begin{array}{l}\text { SH-SY5Y (in vitro) } \\
\text { Rotenone-induced rat } \\
\text { model of PD (in vivo) }\end{array}$ & $\begin{array}{c}\text { Antioxidant } \\
\text { properties } \\
\text { Protect } \\
\text { dopaminergic neurons }\end{array}$ & $\begin{array}{c}\text { Downregulated the expression of Bax, } \\
\text { caspases-3, 6, 8, and 9, cytosolic cyt c; } \\
\text { increased Bcl-2 expression, } \\
\text { Increased SOD, CAT, GPx, } \\
\text { Decreased LPO }\end{array}$ & {$[70,71]$} \\
\hline Leaf powder & $\begin{array}{c}\text { Diazepam-, } \\
\text { scopolamine- and } \\
\text { ageing-induced } \\
\text { amnesia behavioral } \\
\text { models in rats } \\
\text { (in vivo) }\end{array}$ & $\begin{array}{l}\text { Nootropic effect } \\
\text { pro-cholinergic } \\
\text { activity }\end{array}$ & $\begin{array}{l}\text { Improved memory and } \\
\text { learning impairment, } \\
\text { Decreased AChE and total } \\
\text { cholesterol levels }\end{array}$ & {$[63,64]$} \\
\hline Linalool & $\begin{array}{l}\text { A } \beta 1-42 \text {-treated rats } \\
\text { (in vivo) }\end{array}$ & $\begin{array}{l}\text { Antioxidant } \\
\text { properties }\end{array}$ & $\begin{array}{l}\text { Cognitive-enhancing effects, } \\
\text { anti-apoptotic activities, } \\
\text { NMDA receptor antagonist }\end{array}$ & {$[104,106,107]$} \\
\hline Mahanimbine & $\begin{array}{l}\text { SK-N-SH (in vitro) } \\
\text { ICR mouse (in vivo) }\end{array}$ & $\begin{array}{c}\text { Antioxidant } \\
\text { properties, } \\
\text { Anti-inflammatory }\end{array}$ & $\begin{array}{l}\text { Inhibited BACE1 and AChE, } \\
\text { Decreased IL- } 1 \beta \text { and TNF- } \alpha, \text { COX2, } \\
\text { Increased TGF- } \beta \text { and IL-10 }\end{array}$ & {$[67,69]$} \\
\hline Methanolic extract & $\begin{array}{l}\text { Two-vessel occlusion } \\
\text { rat model of partial } \\
\text { global cerebral } \\
\text { ischemia (in vivo) }\end{array}$ & Nootropic effect & $\begin{array}{l}\text { Improved memory and } \\
\text { learning impairment }\end{array}$ & {$[62]$} \\
\hline$\beta$-Myrcene & $\begin{array}{c}\text { Global cerebral } \\
\text { ischemia/reperfusion } \\
(\mathrm{I} / \mathrm{R}) \text { in } \\
\text { C57BL/J6 mice }\end{array}$ & $\begin{array}{l}\text { Antioxidant } \\
\text { properties }\end{array}$ & $\begin{array}{l}\text { Protection against oxidative stress, } \\
\text { apoptosis, and histopathological damage }\end{array}$ & {$[107]$} \\
\hline Nerolidol & $\begin{array}{l}\text { Rotenone-induced } \\
\text { model of PD (in vivo) }\end{array}$ & $\begin{array}{c}\text { Antioxidant } \\
\text { properties, } \\
\text { Anti-inflammatory }\end{array}$ & $\begin{array}{c}\text { Increased SOD, CAT, GSH, } \\
\text { Decreased MDA inhibits the release of } \\
\text { pro-inflammatory cytokines and } \\
\text { inflammatory mediators, } \\
\text { Prevented rotenone-induced } \\
\text { activation of glial cells, } \\
\text { Improved locomotor activity and } \\
\text { cognitive impairment, } \\
\text { Reduced the AChE activity }\end{array}$ & {$[100,111,112]$} \\
\hline Spathulenol & SH-SY5Y (in vitro) & $\begin{array}{l}\text { Antioxidant } \\
\text { properties }\end{array}$ & $\begin{array}{l}\text { Maintained mitochondrial } \\
\text { membrane integrity }\end{array}$ & {$[101]$} \\
\hline
\end{tabular}




\section{Clinical Studies}

Currently, no significant clinical trials have been conducted on curry leaves. A randomized controlled clinical trial was conducted to evaluate the efficacy of M. koenigii and chlorhexidine gluconate for the treatment of gingivitis [113]. In another study, curry leaf powder ( $5 \mathrm{~g}$ daily for 45 days) was given to volunteers to evaluate its effect on liver and renal functions, and no harmful effect was observed on the functions of both the liver and kidney [114]. An herbal medicine containing curry leaves along with pomegranate and turmeric was developed for the treatment of irritable bowel syndrome patients [115]. The effect of curry leaves was also investigated in hypertensive subjects [116]. However, despite numerous in vivo and in vitro studies exploring the neuroprotective potential of $M$. koenigii, the research was lacking on its preclinical and/or clinical efficacy. Therefore, there is an urgent need to conduct clinical trials to prove the neuroprotective capacity of M. koenigii.

\section{Toxicity of Murraya koenigii Leaves}

Curry leaves were rich in calcium, potassium, magnesium, and phosphorous, along with trace amounts of zinc, manganese, selenium, and iron. Additionally, lead, mercury, and cadmium were also present, but below the US FDA limits [117]. Various leaf samples of $M$. koenigii were collected from different regions, and their elemental analyses were performed by the instrumental neutron activation (INAA) and atomic absorption spectrophotometry (AAS). Mean elemental contents varied owing to different climate, soil, and other geoenvironmental conditions. The changes in plants grown on polluted soils revealed the higher levels of heavy metals, which posed a major health concern, where they could affect kidney, liver, and the central nervous system [118].

No signs of mortality or morbidity were seen in either male or female rats fed the ethanolic extract of M. koenigii leaf ( 300 and $500 \mathrm{mg} / \mathrm{kg}$ ) for 28 days. In addition, no mortality was observed at higher doses $(900 \mathrm{mg} / \mathrm{kg})$, but congestion, hemorrhage, and lymphocyte infiltration were recorded. The study concluded that the safety consumption could be high as $500 \mathrm{mg} / \mathrm{kg}$ dosage without inducing any structural damage to the organs [118]. Similarly, no mortality or toxicity signs were observed in another toxicological study of Malaysian MKL. For MKL methanolic extract an $\mathrm{LD}_{50}=200 \mathrm{mg} / \mathrm{kg} /$ day was reported [119]. In addition, mice fed with the mahanine-enriched fraction (MEF) at different doses $(5000 \mathrm{mg} / \mathrm{kg}$ BW single dose, 300-1500 mg/kg BW/day for 14 days, and $300 \mathrm{mg} / \mathrm{kg}$ BW for 180 days) did not exhibit significant toxicity, mortality, or behavioral changes [120]. Another study suggested that crude leaf powder and methanolic leaf extract was safe up to $9000 \mathrm{mg} / \mathrm{kg}$ in mice [121] However, methanolic leaf extract was found to be moderately toxic $\left(\mathrm{LD}_{50}=316.23 \mathrm{mg} / \mathrm{kg}\right.$ body weight) to rats and to cause liver inflammation. However, this dose had no severe side effects on other organs [31].

\section{Conclusions and Future Directions}

Traditional medicinal plants have gained importance during the last few decades, and evidence has been presented for their therapeutic actions, allowing the traditional knowledge of plants to be streamlined with the modern system of medicine to achieve health benefits. This review presented substantial evidence in relation to the mechanistic aspects of $M$. koenigii leaves in ameliorating several neurodegenerative disorders. M. koenigii leaves are an integral part of Indian cuisine and are used for various ailments traditionally. Carbazole alkaloids are abundantly found in species of the Rutaceae family including M. koenigii (Curry leaves). Both the natural and synthetic derivatives of carbazole alkaloids revealed numerous pharmacological activities, including neuroprotection. The M. koenigii leaf extracts and their bioactive compounds, including carbazole alkaloids, sesquiterpenoids, and monoterpenoids, exhibited a multi-target approach by alleviating the oxidative stress, attenuating proinflammatory cytokines, inhibiting AChE and BACE 1, preventing/reducing $A \beta$ protein aggregation, and improving cognitive dysfunction. Thus, $M$. koenigii leaves, their extracts, or purified compounds could offer a beneficial alterna- 
tive therapy to treat NDs through their multi-targeted neuroprotective properties and by improving cholinergic transmissions. Hence, the bioactive compounds from the leaves can serve as lead molecules in future drug discovery. Moreover, there have been no safety concerns associated with the use of $M$. koenigii leaves. Therefore, it is highly recommended to determine effective dose of leaves or their compounds in human for future clinical trials on NDs.

Author Contributions: Conceptualization, N.S. and S.S.A.A.; writing-original draft preparation, N.S. and M.A.T.; writing—review and editing, N.S., M.A.T. and S.S.A.A.; funding acquisition, S.S.A.A. All authors read and agreed to the final version of the manuscript.

Funding: This research was funded by the National Research Foundation of Korea by the Korean Government (2020R1A2B5B01002463 and 2021R1A6A1A03038996).

Institutional Review Board Statement: Not applicable.

Informed Consent Statement: Not applicable.

Data Availability Statement: Data sharing not applicable.

Conflicts of Interest: The authors declare no conflict of interest.

\section{References}

1. Alzheimer's Association Report. 2020 Alzheimer's disease facts and figures. Alzheimer's Dement. 2020, 16, 391-460. [CrossRef] [PubMed]

2. $\quad$ Prince, M.; Guerchet, M.; Prina, M. World Alzheimer Report 2013; Alzheimer's Disease International: London, UK, 2013.

3. Dorsey, E.R.; Constantinescu, R.; Thompson, J.P.; Biglan, K.M.; Holloway, R.G.; Kieburtz, K.; Marshall, F.J.; Ravina, B.M.; Schifitto, G.; Siderowf, A.; et al. Projected number of people with Parkinson disease in the most populous nations, 2005 through 2030. Neurology 2007, 68, 384-386. [CrossRef] [PubMed]

4. Hodjat, M.; Rahmani, S.; Khan, F.; Niaz, K.; Navaei-Nigjeh, M.; Nejad, S.M.; Abdollahi, M. Environmental toxicants, incidence of degenerative diseases, and therapies from the epigenetic point of view. Archiv. Toxicol. 2017, 91, 2577-2597. [CrossRef]

5. Newman, D.J.; Cragg, G.M. Natural products as sources of new drugs over the 30 years from 1981 to 2010. J. Nat. Prod. 2012, 75, 311-335. [CrossRef]

6. Abushouk, A.I.; Negida, A.; Ahmed, H.; Abdel-Daim, M.M. Neuroprotective mechanisms of plant extracts against MPTP induced neurotoxicity: Future applications in Parkinson's disease. Biomed. Pharmacother. 2017, 85, 635-645. [CrossRef] [PubMed]

7. Cui, X.; Lin, Q.; Liang, Y. Plant-derived antioxidants protect the nervous system from aging by inhibiting oxidative stress. Front. Aging Neurosci. 2020, 12, 209. [CrossRef] [PubMed]

8. Hussain, G.; Rasul, A.; Anwar, H.; Aziz, N.; Razzaq, A.; Wei, W.; Ali, M.; Li, J.; Li, X. Role of plant derived alkaloids and their mechanism in neurodegenerative disorders. Intern. J. Biol. Sci. 2018, 14, 341-357. [CrossRef]

9. Prasansuklab, A.; Brimson, J.M.; Tencomnao, T. Potential Thai medicinal plants for NDss: A review focusing on the anti-glutamate toxicity effect. J. Tradit. Complement. Med. 2020, 10, 301-308. [CrossRef]

10. Witter, S.; Witter, R.; Vilu, R.; Samoson, A. Medical plants and nutraceuticals for amyloid- $\beta$ fibrillation inhibition. J. Alzheimers Dis. Rep. 2018, 2, 239-252. [CrossRef]

11. Mittal, J. Curry Leaf (Murraya koenigii): A Spice with Medicinal Property. MOJ Biol. Med. 2017, 2, 236-256. [CrossRef]

12. Husna, F.; Suyatna, F.D.; Arozal, W.; Poerwaningsih, E.H. Anti-diabetic potential of Murraya koenigii (L.) and its antioxidant capacity in nicotinamide-streptozotocin induced diabetic rats. Drug Res. 2018, 68, 631-636. [CrossRef] [PubMed]

13. Kesari, A.N.; Kesari, S.; Singh, S.K.; Gupta, R.K.; Watal, G. Studies on the glycemic and lipidemic effect of Murraya koenigii in experimental animals. J. Ethnopharm. 2007, 112, 305-311. [CrossRef]

14. Lawal, H.; Atiku, M.K.; Khelpai, D.G.; Wannang, N.N. Hypoglycaemic and hypolipidaemic effects of the aqueous leaf extract of Murraya koenigii in normal and alloxan-diabetic rats. Niger. J. Physiol. Sci. 2008, 23, 37-40. [CrossRef]

15. Phatak, R.S.; Khanwelkar, C.C.; Matule, S.M.; Datkhile, K.D.; Hendre, A.S. Antihyperlipidemic activity of Murraya koenigii leaves methanolic and aqueous extracts on serum lipid profile of high fat-fructose fed rats. Pharmacog. J. 2019, 11, 836-841. [CrossRef]

16. Mahipal, P.; Pawar, R.S. Nephroprotective effect of Murraya koenigii on cyclophosphamide induced nephrotoxicity in rats. Asian Pac. J. Trop. Med. 2017, 10, 808-812. [CrossRef] [PubMed]

17. Yankuzo, H.; Ahmed, Q.U.; Santosa, R.I.; Akter, S.F.; Talib, N.A. Beneficial effect of the leaves of Murraya koenigii (Linn.) Spreng (Rutaceae) on diabetes-induced renal damage in vivo. J. Ethnopharmacol. 2011, 135, 88-94. [CrossRef]

18. Desai, S.N.; Patel, D.K.; Devkar, R.V.; Patel, P.V.; Ramachandran, A.V. Hepatoprotective potential of polyphenol rich extract of Murraya koenigii L.: An in vivo study. Food Chem. Toxicol. 2012, 50, 310-314. [CrossRef]

19. Sathaye, S.; Bagul, Y.; Gupta, S.; Kaur, H.; Redkar, R. Hepatoprotective effects of aqueous leaf extract and crude isolates of Murraya koenigii against in vitro ethanol-induced hepatotoxicity model. Exp. Toxicol. Pathol. 2011, 63, 587-591. [CrossRef] 
20. Firdaus, S.B.; Ghosha, D.; Chattyopadhyay, A.; Duttaa, M.; Paul, S.; Janac, J.; Basua, A.; Bosea, G.; Lahiri, H.; Banerjee, B.; et al. Protective effect of antioxidant rich aqueous curry leaf (Murraya koenigii) extract against gastro-toxic effects of piroxicam in male Wistar rats. Toxicol. Rep. 2014, 1, 987-1003. [CrossRef]

21. Kadam, S.H.; Dombe, S.; Naikwadi, P. Cardiovascular effects of aqueous extract of Murraya koenigii on isolated perfused frog heart preparation. J. Pharm. Res. 2011, 4, 462-463.

22. Sandamali, J.A.; Hewawasam, R.P.; Jayatilaka, K.A.; Mudduwa, L.K. Cardioprotective potential of Murraya koenigii (L.) Spreng. leaf extract against doxorubicin-induced cardiotoxicity in rat. Evid.-Based Complement. Altern. Med. 2020, 2020, 6023737. [CrossRef]

23. Ambreen, G.; Siddiq, A.; Hussain, K.; Hussain, A.S.; Naz, Z. Repeatedly heated mix vegetable oils induced atherosclerosis and effects of Murraya koenigii. BMC Complement. Med. Ther. 2020, 20, 222. [CrossRef] [PubMed]

24. Xie, J.; Chang, W.; Wang, C.; Mehendale, S.R.; Li, J.; Ambihaipahar, R.; et. al. Curry leaf (Murraya koenigii Spreng.) reduces blood cholesterol and glucose levels in ob/ob mice. Am. J. Chin. Med. 2006, 34, 279-284. [CrossRef] [PubMed]

25. Gupta, S.; Prakash, J. Studies on Indian green leafy vegetables for their antioxidant activity. Plant Foods Hum. Nutr. 2009, 64, 39-45. [CrossRef] [PubMed]

26. Rajendran, M.P.; Pallaiyan, B.B.; Selvaraj, N. Chemical composition, antibacterial and antioxidant profile of essential oil from Murraya koenigii (L.) leaves. Avicenna J. Phytomed. 2014, 4, 200-214. [PubMed]

27. Gupta, S.; George, M.; Singhal, M.; Sharma, G.N.; Garg, V. Leaves extract of Murraya koenigii Linn for anti-inflammatory and analgesic activity in animal models. J. Adv. Pharm. Technol. Res. 2010, 1, 68.

28. Khurana, A.; Sikha, M.S.; Ramesh, K.; Venkatesh, P.; Godugu, C. Modulation of cerulein-induced pancreatic inflammation by hydroalcoholic extract of curry leaf (Murraya koenigii). Phytother. Res. 2019, 33, 1510-1525. [CrossRef]

29. Muthumani, P.; Venkatraman, S.; Ramseshu, K.V.; Meera, R.; Devi, P.; Kameswari, B. Pharmacological studies of anticancer, anti-inflammatory activities of Murraya koenigii (Linn) Spreng in experimental animals. J. Pharm. Sci. Res. 2009, 1, 137-141.

30. Pokala, N.; Sayeli, V. Evaluation of antipyretic activity of alcoholic extract of Murraya koenigii leaves in rabbits. Int. J. Basic Clin. Pharmacol. 2019, 8, 1577. [CrossRef]

31. Adebajo, A.C.; Ayoola, O.F.; Iwalewa, E.O.; Akindahunsi, A.A.; Omisore, N.O.; Adewunmi, C.O.; Adenowo, T.K. Antitrichomonal, biochemical and toxicological activities of methanolic extract and some carbazole alkaloids isolated from the leaves of Murraya koenigii growing in Nigeria. Phytomedicine 2006, 13, 246-254. [CrossRef]

32. Ningappa, M.B.; Dhananjaya, B.L.; Dinesha, R.; Harsha, R.; Srinivas, L. Potent antibacterial property of APC protein from curry leaves (Murraya koenigii L.). Food Chem. 2010, 118, 747-750. [CrossRef]

33. Thi Nguyen, T.; Diep, T.T.; Hoang, V.; Mai Vo, T.H.; Duus, F.; Ngoc Le, T. Investigation of curry leaf essential oils of Murraya koenigii Spreng. growing in the South of Vietnam. J. Essent. Oil-Bear. Plants 2012, 15, 1021-1029. [CrossRef]

34. Tripathi, Y.; Anjum, N.; Rana, A. Chemical composition and in vitro antifungal and antioxidant activities of essential oil from Murraya koenigii (L.) Spreng. Leaves. Asian J. Biomed. Pharm. Sci. 2018, 8, 6-13. [CrossRef]

35. Roy, S.; Dutta, D.; Satyavarapu, E.M.; Yadav, P.K.; Mandal, C.; Kar, S.; Mandal, C. Mahanine exerts in vitro and in vivo antileishmanial activity by modulation of redox homeostasis. Sci. Rep. 2017, 7, 4141. [CrossRef] [PubMed]

36. Mandal, S.; Nayak, A.; Kar, M.; Banerjee, S.K.; Das, A.; Upadhyay, S.N.; Singh, R.K.; Banerji, A.; Banerji, J. Antidiarrhoeal activity of carbazole alkaloids from Murraya koenigii Spreng (Rutaceae) seeds. Fitoterapia 2010, 81, 72-74. [CrossRef] [PubMed]

37. Nagappan, T.; Segaran, T.C.; Wahid, M.E.; Ramasamy, P.; Vairappan, C.S. Efficacy of carbazole alkaloids, essential oil and extract of Murraya koenigii in enhancing subcutaneous wound healing in rats. Molecules 2012, 17, 14449-14463. [CrossRef]

38. Tembhurne, S.V.; Sakarkar, D.M. Anti-obesity and hypoglycemic effect of ethanolic extract of Murraya koenigii (L.) leaves in high fatty diet rats. Asian Pac. J. Trop. Dis. 2012, 2, S166-S168. [CrossRef]

39. Amna, U.; Halimatussakdiah, P.W.; Saidi, N.; Nasution, R. Evaluation of cytotoxic activity from Temurui (Murraya koenigii [Linn.] Spreng) leaf extracts against HeLa cell line using MTT assay. J. Adv. Pharm. Technol. Res. 2019, 10, 51-55. [CrossRef]

40. Sanaye, M.; Pagare, N. Evaluation of antioxidant effect and anticancer activity against human glioblastoma (U373MG) cell lines of Murraya Koenigii. Pharmacog. J. 2016, 8, 220-225. [CrossRef]

41. Yeap, S.K.; Abu, N.; Mohamad, N.E.; Beh, B.K.; Ho, W.Y.; Ebrahimi, S.; Yusof, H.M.; Ky, H.; Tan, S.W.; Alitheen, N.B. Chemopreventive and immunomodulatory effects of Murraya koenigii aqueous extract on 4T1 breast cancer cell-challenged mice. BMC Complement. Altern. Med. 2015, 4, 306. [CrossRef]

42. Paul, S.; Bandyopadhyay, T.K.; Bhattacharyya, A. Immunomodulatory effect of leaf extract of Murraya koenigii in diabetic mice. Immunopharmacol. Immunotoxicol. 2011, 33, 691-699. [CrossRef] [PubMed]

43. Shah, A.S.; Wakade, A.S.; Juvekar, A.R. Immunomodulatory activity of methanolic extract of Murraya koenigii (L) Spreng. Leaves. Indian J. Exp. Biol. 2008, 46, 505-509. [PubMed]

44. Ito, C.; Itoigawa, M.; Nakao, K.; Murata, T.; Tsuboi, M.; Kaneda, N.; Furukawa, H. Induction of apoptosis by carbazole alkaloids isolated from Murraya koenigii. Phytomedicine 2006, 13, 359-365. [CrossRef] [PubMed]

45. Bhattacharya, K.; Samanta, S.K.; Tripathi, R.; Mallick, A.; Chandra, S.; Pal, B.C.; Shaha, C.; Mandal, C. Apoptotic effects of mahanine on human leukemic cells were mediated through crosstalk between Apo-1/Fas signaling and the Bid protein and via mitochondrial pathways. Biochem. Pharmacol. 2010, 79, 361-372. [CrossRef]

46. Chen, M.; Yin, X.; Lu, C.; Chen, X.; Ba, H.; Cai, J.; Sun, J. Mahanine induces apoptosis, cell cycle arrest, inhibition of cell migration, invasion and PI3K/AKT/mTOR signalling pathway in glioma cells and inhibits tumor growth in vivo. Chem. Biol. Interact. 2019, 299, 1-7. [CrossRef] [PubMed] 
47. Noolu, B.; Ajumeera, R.; Chauhan, A.; Nagalla, B.; Manchala, R.; Ismail, A. Murraya koenigii leaf extract inhibits proteasome activity and induces cell death in breast cancer cells. BMC Complement. Altern. Med. 2013, 13, 7. [CrossRef] [PubMed]

48. Samanta, S.K.; Kandimalla, R.; Gogoi, B.; Dutta, K.N.; Choudhury, P.; Deb, P.K.; et. al. Phytochemical portfolio and anticancer activity of Murraya koenigii and its primary active component, mahanine. Pharmacol. Res. 2018, 129, 227-236. [CrossRef]

49. Biswas, A.; Bhattacharya, S.; Dasgupta, S.; Kundu, R.; Roy, S.S.; Pal, B.C.; Bhattacharya, S. Insulin resistance due to lipid-induced signaling defects could be prevented by mahanine. Mol. Cell. Biochem. 2010, 336, 97-107. [CrossRef]

50. Igara, C.E.; Omoboyowa, D.A.; Ahuchaogu, A.A.; Orji, N.U.; Ndukwe, M.K. Phytochemical and nutritional profile of Murraya koenigii (Linn) Spreng leaf. J. Pharmacog. Phytochem. 2016, 5, 7-9.

51. Bhandari, P.R. Curry leaf (Murraya koenigii) or cure leaf: Review of its curative properties. J. Med. Nutr. Nutraceut. $2012,1,92-97$. [CrossRef]

52. Balakrishnan, R.; Vijayraja, D.; Jo, S.-H.; Ganesan, P.; Su-Kim, I.; Choi, D.-K. Medicinal profile, phytochemistry, and pharmacological activities of Murraya koenigii and its primary bioactive compounds. Antioxidants 2020, 9, 101. [CrossRef]

53. Wei, R.; Ma, Q.; Zhong, G.; Su, Y.; Yang, J.; Wang, A.; Ji, T.; Guo, H.; Wang, M.; Jiang, P.; et al. Structural characterization, hepatoprotective and antihyperlipidemic activities of alkaloid derivatives from Murraya koenigii. Phytochem. Lett. 2020, 35 , 135-140. [CrossRef]

54. Abeysinghe, D.T.; Alwis, D.D.; Kumara, K.A.; Chandrika, U.G. Nutritive importance and therapeutics uses of three different varieties (Murraya koenigii, Micromelum minutum, and Clausena indica) of curry leaves: An updated review. Evid.-Based Complement. Altern. Med. 2021, 2021, 5523252. [CrossRef]

55. Rana, V.S.; Juyal, J.P.; Blazquez, M.A. Chemical constituents of the volatile oil of Murraya koenigii leaves. Int. J. Aromather. 2004, 14, 23-25. [CrossRef]

56. Nagappan, T.; Ramasamy, P.; Vairappan, C.S. Chemotaxonomical markers in essential oil of Murraya koenigii. Nat. Prod. Commun 2012, 7, 1375-1378. [CrossRef]

57. Rao, B.R. Curry Leaf (Murraya koenigii) Oils. In Essential Oils in Food Preservation, Flavor and Safety; Academic Press: Cambridge, MA, USA, 2016; pp. 385-394.

58. Reddy, B.M.; Dhanapal, C.K.; Lakshmi, B.V.S. Anti-Alzheimer's Activity of aqueous extract of leaves of Murraya koenigii in Aluminium chloride Induced Neurotoxicity in rats. Res. J. Pharm. Technol. 2019, 12, 1927-1934. [CrossRef]

59. Gill, N.S.; Sharma, B. Study on antioxidant potential of Murraya koenigii leaves in wistar rats. Pak. J. Biol. Sci. 2013, 17, 126-129. [CrossRef]

60. Rehana, D.; Mahendiran, D.; Kumar, R.S.; Rahiman, A.K. In vitro antioxidant and antidiabetic activities of zinc oxide nanoparticles synthesized using different plant extracts. Bioprocess Biosyst. Eng. 2017, 40, 943-957. [CrossRef]

61. Reddy, M.B.; Dhanapal, C.K.; Lakshmi, B.V. Anti-Parkinson activity of aqueous extract of leaves of Murraya koenigii against paraquat-induced Parkinsonism in Wistar rats. Asian J. Pharm. Clin. Res. 2020, 13, 150-153.

62. Azzubaid, M.S.; Al-Ani, I.M. Mnemonic and histopathological assessment of the neuroprotective effects of Murraya koenigii leaves extract in rats with partial global cerebral Ischaemia. IIUM Med. J. Malays. 2019, 18,77-86. [CrossRef]

63. Vasudevan, M.; Parle, M.; Sengottuvelu, S.; Shanmugapriya, T. Nootropic potential of Murraya koenigii leaves in rats. Orient. Phar. Exp. Med. 2008, 8, 365-373. [CrossRef]

64. Vasudevan, M.; Parle, M. Antiamnesic potential of Murraya koenigii leaves. Phytother. Res. 2009, 23, 308-316. [CrossRef]

65. Mani, V.; Ramasamy, K.; Ahmad, A.; Parle, M.; Shah, S.A.A.; Majeed, A.B.A. Protective effects of total alkaloidal extract from Murraya koenigii leaves on experimentally induced dementia. Food Chem. Toxicol. 2012, 50, 1036-1044. [CrossRef]

66. Mani, V.; Ramasamy, K.; Ahmad, A.; Wahab, S.N.; Jaafar, S.M.; Kek, T.L.; Salleh, M.; Majeed, A. Effects of the total alkaloidal extract of Murraya koenigii leaf on oxidative stress and cholinergic transmission in aged mice. Phytother. Res. 2013, 27, 46-53. [CrossRef]

67. Azahan, N.; Mani, V.; Ramasamy, K.; Lim, S.; Alhowail, A.; Sajid, S.; Majeed, A. Neuroprotective potential of mahanimbine against lipopolysaccharides (LPS)-induced neuronal deficits on SK-N-SH cells and antioxidant potentials in ICR mice brain. J. Pharm. Res. Int. 2019, 31, 1-11. [CrossRef]

68. Azahan, N.; Mani, V.; Ramasamy, K.; Lim, S.; James, R.; Alsharidah, M.; Alhowail, A.; Majeed, A. Mahanimbine-induced neuroprotection via cholinergic system and attenuated amyloidogenesis as well as neuroinflammation in lipopolysaccharidesinduced mice. Pharmacog. Mag. 2020, 16, 57-63.

69. Kumar, N.S.; Mukherjee, P.; Bhadra, S.; Saha, B.; Pla, B. Aceylcholinesterase inhibitory potential of a carbazole alkaloid, mahanimbine, from Murraya koenigii. Phytother. Res. 2010, 24, 629-631. [CrossRef]

70. Balakrishnan, R.; Elangovan, N.; Mohankumar, T.; Nataraj, J.; Manivasagam, T.; Thenmozhi, A.J.; Essa, M.; Akbar, M.; Khan, M.S. Isolongifolene attenuates rotenone-induced mitochondrial dysfunction, oxidative stress and apoptosis. Front. Biosci. 2018, 10, 248-261.

71. Balakrishnan, R.; Tamilselvam, K.; Sulthana, A.; Mohankumar, T.; Manimaran, D.; Elangovan, N. Isolongifolene attenuates oxidative stress and behavioral impairment in rotenone-induced rat model of Parkinson's disease. Int. J. Nutr. Pharmacol. Neurol. Dis. 2018, 8, 53-58.

72. Rangasamy, K.; Namasivayam, E. In vitro antioxidant and free radical scavenging activity of isolongifolene. Asian J. Biol. Sci. 2014, 7, 13-23. [CrossRef] 
73. Nataraj, J.; Manivasagam, T.; Thenmozhi, A.J.; Essa, M.M. Neurotrophic effect of asiatic acid, a triterpene of Centella asiatica against chronic 1-methyl 4-phenyl 1, 2, 3, 6-tetrahydropyridine hydrochloride/probenecid mouse model of Parkinson's disease: The role of MAPK, PI3K-Akt-GSK3 $\beta$ and mTOR signalling pathways. Neurochem. Res. 2017, 42, 1354-1365.

74. Parekh, D.B.; Ziegler, W.; Parker, P.J. Multiple pathways control protein kinase C phosphorylation. EMBO J. 2000, 19, 496-503 [CrossRef]

75. Wills, J.; Jones, J.; Haggerty, T.; Duka, V.; Joyce, J.N.; Sidhu, A. Elevated tauopathy and alpha-synuclein pathology in postmortem Parkinson's disease brains with and without dementia. Exp. Neurol. 2010, 225, 210-218. [CrossRef]

76. Yang, J.; Takahashi, Y.; Cheng, E.; Liu, J.; Terranova, P.F.; Zhao, B.; Thrasher, J.B.; Wang, H.; Li, B. GSK-3 $\beta$ promotes cell survival by modulating Bif-1-dependent autophagy and cell death. J. Cell Sci. 2010, 123, 861-870. [CrossRef]

77. King, T.D.; Clodfelder-Miller, B.; Barksdale, K.A.; Bijur, G.N. Unregulated mitochondrial GSK3 $\beta$ activity results in NADH: Ubiquinone oxidoreductase deficiency. Neurotox. Res. 2008, 14, 367-382. [CrossRef]

78. Chowdhury, J.U.; Bhuiyan, M.N.; Yusuf, M. Chemical composition of the leaf essential oils of Murraya koenigii (L.) Spreng and Murraya paniculata (L.) Jack. Bangladesh J. Pharmacol. 2008, 3, 59-63. [CrossRef]

79. Dhopeshwarkar, A.; Mackie, K. CB2 cannabinoid receptors as a therapeutic target-What does the future hold? Mol. Pharmacol. 2014, 86, 430-437. [CrossRef]

80. Cassano, T.; Calcagnini, S.; Pace, L.; De Marco, F.; Romano, A.; Gaetani, S. Cannabinoid receptor 2 signaling in neurodegenerative disorders: From pathogenesis to a promising therapeutic target. Front. Neurosci. 2017, 11, 30. [CrossRef]

81. Patel, K.D.; Davison, J.S.; Pittman, Q.J.; Sharkey, K.A. Cannabinoid CB2 receptors in health and disease. Curr. Med. Chem. 2010 17, 1394-1410. [CrossRef]

82. Centonze, D.; Bari, M.; Rossi, S.; Prosperetti, C.; Furlan, R.; Fezza, F.; De Chiara, V.; Battistini, L.; Bernardi, G.; Bernardini, S.; et al The endocannabinoid system was dysregulated in multiple sclerosis and in experimental autoimmune encephalomyelitis. Brain 2007, 130, 2543-2553. [CrossRef]

83. Di Filippo, M.; Pini, L.A.; Pelliccioli, G.P.; Calabresi, P.; Sarchielli, P. Abnormalities in the cerebrospinal fluid levels of endocannabinoids in multiple sclerosis. J. Neurol. Neurosurg. Psychiatry 2008, 79, 1224-1229. [CrossRef]

84. Benito, C.; Romero, J.P.; Tolón, R.M.; Clemente, D.; Docagne, F.; Hillard, C.J.; Guaza, C.; Romero, J. Cannabinoid CB1 and CB2 receptors and fatty acid amide hydrolase were specific markers of plaque cell subtypes in human multiple sclerosis. J. Neurosci. 2007, 27, 2396-2402. [CrossRef]

85. Yiangou, Y.; Facer, P.; Durrenberger, P.; Chessell, I.P.; Naylor, A.; Bountra, C.; Banati, R.; Anand, P. COX-2, CB2 and P2X7immunoreactivities were increased in activated microglial cells/macrophages of multiple sclerosis and amyotrophic lateral sclerosis spinal cord. BMC Neurol. 2006, 6, 12. [CrossRef]

86. Benito, C.; Núñez, E.; Tolón, R.M.; Carrier, E.J.; Rábano, A.; Hillard, C.J.; Romero, J. Cannabinoid CB2 receptors and fatty acid amide hydrolase were selectively overexpressed in neuritic plaque-associated glia in Alzheimer's disease brains. J. Neurosci. 2003, 23, 11136-11141. [CrossRef]

87. Ramírez, B.G.; Blázquez, C.; del Pulgar, T.G.; Guzmán, M.; de Ceballos, M.L. Prevention of Alzheimer's disease pathology by cannabinoids: Neuroprotection mediated by blockade of microglial activation. J. Neurosci. 2005, 25, 1904-1913. [CrossRef]

88. Westlake, T.M.; Howlett, A.C.; Bonner, T.I.; Matsuda, L.A.; Herkenham, M. Cannabinoid receptor binding and messenger RNA expression in human brain: An in vitro receptor autoradiography and in situ hybridization histochemistry study of normal aged and Alzheimer's brains. Neuroscience 1994, 63, 637-652. [CrossRef]

89. Farooqui, A.A.; Liss, L.; Horrocks, L.A. Stimulation of lipolytic enzymes in Alzheimer's disease. In Lipid Storage Disorders, Springer: Boston, MA, USA, 1988; pp. 689-698.

90. Johnson, S.A.; Rodriguez, D.; Allred, K. A systematic review of essential oils and the endocannabinoid system: A connection worthy of further exploration. Evid.-Based Complement. Altern. Med. 2020, 2020, 8035301. [CrossRef]

91. Chávez-Hurtado, P.; González-Castaneda, R.E.; Beas-Zarate, C.; Flores-Soto, M.E.; Viveros-Paredes, J.M. $\beta$-Caryophyllene reduces DNA oxidation and the overexpression of glial fibrillary acidic protein in the prefrontal cortex and hippocampus of D-galactose-induced aged BALB/c mice. J. Med. Food 2020, 23, 515-522. [CrossRef]

92. Fontes, L.B.; Dias, D.D.; Aarestrup, B.J.; Aarestrup, F.M.; Da Silva Filho, A.A.; do Amaral Corrêa, J.O. $\beta$-Caryophyllene ameliorates the development of experimental autoimmune encephalomyelitis in C57BL/6 mice. Biomed. Pharmacother. 2017, 91, 257-264. [CrossRef]

93. Askari, V.R.; Shafiee-Nick, R. Promising neuroprotective effects of $\beta$-caryophyllene against LPS-induced oligodendrocyte toxicity: A mechanistic study. Biochem. Pharmacol. 2019, 159, 154-171. [CrossRef]

94. Cheng, Y.; Dong, Z.; Liu, S. $\beta$-Caryophyllene ameliorates the Alzheimer-like phenotype in APP/PS1 Mice through CB2 receptor activation and the PPAR $\gamma$ pathway. Pharmacology 2014, 94, 1-12. [CrossRef]

95. Chang, H.J.; Kim, J.M.; Lee, J.C.; Kim, W.K.; Chun, H.S. Protective effect of $\beta$-caryophyllene, a natural bicyclic sesquiterpene, against cerebral ischemic injury. J. Med. Food 2013, 16, 471-480. [CrossRef]

96. Yang, M.; Lv, Y.; Tian, X.; Lou, J.; An, R.; Zhang, Q.; Li, M.; Xu, L.; Dong, Z. Neuroprotective effect of $\beta$-caryophyllene on cerebral ischemia-reperfusion injury via regulation of necroptotic neuronal death and inflammation: In vivo and in vitro. Front. Neurosci. 2017, 11, 583. [CrossRef] 
97. Hashiesh, H.M.; Sharma, C.; Goyal, S.N.; Sadek, B.; Jha, N.K.; Al Kaabi, J.; Ojha, S. A focused review on CB2 receptor-selective pharmacological properties and therapeutic potential of $\beta$-caryophyllene, a dietary cannabinoid. Biomed. Pharmacother. 2021, 140, 111639. [CrossRef]

98. Francomano, F.; Caruso, A.; Barbarossa, A.; Fazio, A.; La Torre, C.; Ceramella, J.; et. al. $\beta$-Caryophyllene: A sesquiterpene with countless biological properties. Appl. Sci. 2019, 9, 5420. [CrossRef]

99. Machado, K.D.; Islam, M.T.; Ali, E.S.; Rouf, R.; Uddin, S.J.; Dev, S.; et. al. A systematic review on the neuroprotective perspectives of beta-caryophyllene. Phytother. Res. 2018, 32, 2376-2388. [CrossRef]

100. Nagappan, T.; Ramasamy, P.; Wahid, M.E.; Segaran, T.C.; Vairappan, C.S. Biological activity of carbazole alkaloids and essential oil of Murraya koenigii against antibiotic resistant microbes and cancer cell lines. Molecules 2011, 16, 9651-9664. [CrossRef]

101. Manjima, R.B.; Ramya, S.; Kavitha, K.; Paulpandi, M.; Saranya, T.; Winster, S.; Balachandar, V.; Arul, N. Spathulenol attenuates 6-hydroxydopamine induced neurotoxicity in SH-SY5Y neuroblastoma cells. Gene Rep. 2021, 25, 101396. [CrossRef]

102. Miyazawa, M.; Yamafuji, C. Inhibition of acetylcholinesterase activity by bicyclic monoterpenoids. J. Agri. Food Chem. 2005, 53, 1765-1768. [CrossRef]

103. Abuhamdah, S.; Abuhamdah, R.; Howes, M.J.; Uttley, G.; Chazot, P.L. A Molecular Docking Study of Aloysia citrodora Palau. Leaf Essential Oil Constituents towards Human Acetylcholinesterase: Implications for Alzheimer's disease. Jordan J. Biol. Sci. 2020, 13, 575-580.

104. Cioanca, O.; Hritcu, L.; Mihasan, M.; Hancianu, M. Cognitive-enhancing and antioxidant activities of inhaled coriander volatile oil in amyloid $\beta$ (1-42) rat model of Alzheimer's disease. Physiol. Behav. 2013, 120, 193-202. [CrossRef]

105. LoPachin, R.M. Acrylamide neurotoxicity: Eurological, morphological and molecular endpoints in animal models. Adv. Exp. Med. Biol. 2005, 561, 21-37.

106. Mehri, S.; Meshki, M.A.; Hosseinzadeh, H. Linalool as a neuroprotective agent against acrylamide-induced neurotoxicity in Wistar rats. Drug Chem. Toxicol. 2015, 38, 162-166. [CrossRef]

107. Silva Brum, L.F.; Emmanuelli, T.; Souza, D.O.; Elisabetsky, E. Effects of linalool on glutamate release and uptake in mouse cortical synaptosomes. Neurochem. Res. 2001, 26, 191-194. [CrossRef]

108. Brum, L.F.; Elisabetsky, E.; Souza, D. Effects of linalool on [(3)H]MK801 and [(3)H] muscimol binding in mouse cortical membranes. Phytother. Res. 2001, 15, 422-425. [CrossRef]

109. Sabogal-Guaqueta, A.M.; Osorio, E.; Cardona-Gomez, G.P. Linaloo reverses neuropathological and behavioral impairments in old triple transgenic Alzheimer's mice. Neuropharmacology 2016, 102, 111-120. [CrossRef]

110. Ciftci, O.; Oztanir, M.N.; Cetin, A. Neuroprotective effects of $\beta$-myrcene following global cerebral ischemia/reperfusion-mediated oxidative and neuronal damage in a C57BL/J6 mouse. Neurochem. Res. 2014, 39, 1717-1723. [CrossRef]

111. Javed, H.; Azimullah, S.; Abul Khair, S.B.; Ojha, S.; Haque, M. Neuroprotective effect of nerolidol against neuroinflammation and oxidative stress induced by rotenone. BMC Neurosci. 2016, 17, 58. [CrossRef]

112. Kaur, A.; Jaiswal, G.; Brar, J.; Kumar, P. Neuroprotective effect of nerolidol in traumatic brain injury associated behavioural comorbidities in rats. Toxicol. Res. 2021, 10, 40-50. [CrossRef]

113. Varghese, A.; Babu, H.M.; Kukkera, P.N. Comparative evaluation of efficacy of Murraya koenigii and chlorhexidine gluconate in the treatment of gingivitis: A randomized controlled clinical trial. J. Indian Soc. Periodontol. 2018, 22, 427-432.

114. Molly, J.; Edison, S.; Vijajaraghavan, R. Effect of Murraya Koenigii (Curry Leaves) powder on the liver and renal functions in women with hyperlipidemia. Int. J. Health Sci. Res. 2017, 7, 188-192.

115. Lauche, R.; Kumar, S.; Hallmann, J.; Lüdtke, R.; Rampp, T.; Dobos, G.; Langhorst, J. Efficacy and safety of Ayurvedic herbs in diarrhoea-predominant irritable bowel syndrome: A randomised controlled crossover trial. Complement. Ther. Med. 2016, 26, 171-177. [CrossRef]

116. Gaikwad, P.; Khan, T.N.; Nalwade, V. Impact of curry leaves (Murraya koenigii) chutney supplementation on hypertensive subjects. Int. J. Food Nutri. Sci. 2013, 2, 68-72.

117. Choudhury, R.P.; Garg, A.N. Variation in essential, trace and toxic elemental contents in Murraya koenigii-A spice and medicinal herb from different Indian states. Food Chem. 2007, 104, 1454-1463. [CrossRef]

118. Sakarkar, D.M.; Tembhume, S.V.; More, B.H. 28 Days repeated dose toxicity study of ethanolic extract of Murraya koenigii in Wistar rats. Ann. Pharmacol. Pharm. 2017, 2, 1047.

119. Azzubaidi, M.S.; Saxena, A.K.; Alattraqchi, A.G.; Abdualkader, A.M. Chronic LD50 vs. safest dose for the methanolic extract of curry leaves (Murraya koenigii) cultivated in Malaysia. J. Appl. Pharm. Sci. 2014, 4, 56-58.

120. Satyavarapu, E.M.; Sinha, P.K.; Mandal, C. Preclinical development of mahanine-enriched fraction from indian spice Murraya koenigii for the management of cancer: Efficacy, temperature/pH stability, pharmacokinetics, acute and chronic toxicity (14-180 days) studies. BioMed Res. Int. 2020, 2020, 4638132. [CrossRef]

121. Apostoli, P. Elements in environmental and occupational medicine. J. Chromatogr. B Analyt. Technol. Biomed. Life Sci. 2002, 778, 63-97. [CrossRef] 